\title{
Faktor-Faktor Yang Mempengaruhi Fraud Dalam Kegiatan Pengadaan Barang dan Jasa
}

Nur Hidayati ${ }^{1}$, J.M.V Mulyadi ${ }^{2}$

${ }^{1.2}$ Universitas Pancasila, Jl. Srengseng Sawah, Jagakarsa, Jakarta Selatan, 12640

INFO ARTIKEL

JEL Classsification:

M41

M42

H5 7

Keywords:

fraud, procurement committee, system and procedures, ethics, internal control.

\section{$A B S T R A C T$}

The purpose of this study is to examine whether variables such as quality of goods/services procurement committee, income of goods/services procurement committee, procurement system and procurement system, procurement ethic of goods/services and internal control system have influence to fraud of goods/ services procurement in the ministry of health affairs agency. Population in this research is all auditor related in process of procurement of goods/services, while the object of research (sample) that is as much as 56 people. The technique of determining the sample using purposive sampling method. Data were tested using validity test, reliability test, multicolinearity test, heteroskedasticity test, multiple regression analysis, hypothesis test and coefficient of determination. The result of the research shows that the quality of procurement committee variables significantly and negatively affect the fraud of procurement of goods/services. The income of the procurement committee does not significantly affect the procurement of goods/ services, procurement system and procedures have significant effect and negative to the goods/ service procurement, ethics have significant effect and negative to the procurement of goods/services and internal control system significantly and negative to the fraud of procurement of goods / services.

\section{A B S T R A K}

Tujuan dari penelitian ini adalah untuk menguji apakah variabel seperti kualitas panitia pengadaan barang/jasa, penghasilan panitia pengadaan barang/ jasa, sistem dan prosedur pengadaan barang/jasa, etika pengadaan barang/jasa, dan sistem pengendalian internal memiliki pengaruh terhadap fraud pengadaan barang/jasa di Lingkungan Instansi Kementerian Kesehatan RI. Populasi dalam penelitian ini adalah seluruh auditor yang terkait dalam proses pengadaan barang/ jasa, sedangkan yang dijadikan objek penelitian (sampel) yaitu sebanyak 56 orang. Teknik penentuan sampel menggunakan metode purposive sampling. Data diuji menggunakan uji validitas, uji reliabilitas, uji multikolinearitas, uji heteroskedastisitas, analisis regresi berganda, uji hipotesis dan koefisien determinasi. Hasil penelitian menunjukkan bahwa variabel kualitas panitia pengadaan berpengaruh secara signifikan dan negatif terhadap fraud pengadaan barang/jasa. Penghasilan panitia pengadaan tidak berpengaruh secara signifikan terhadap terhadap fraud pengadaan barang/jasa, sistem dan prosedur pengadaan berpengaruh secara signifikan dan negatif terhadap fraud pengadaan barang/jasa, etika berpengaruh secara signifikan dan negatif terhadap fraud pengadaan barang/ jasa dan sistem pengendalian internal berpengaruh secara signifikan dan negatif terhadap fraud pengadaan barang/jasa.

*Email Korespondensi: 'nurhida.janeeta@gmail.com,.2mulyadi@univpancasila.ac.id 


\section{Pendahuluan}

Fraud yang terjadi di sektor publik berupa korupsi (corruption), penyalahgunaan aset (asset misappropriation), maupun pernyataan palsu atau salah pernyataan (fraudulent statements). Fraud tersebut dapat dikategorikan sebagai tindak pidana korupsi (seperti disebutkan dalam Undang-Undang No. 31 tahun 1999 junto Undang-Undang No. 20 tahun 2001 yang menyatakan bahwa perbuatan curang dan perbuatan yang merugikan keuangan negara merupakan jenis-jenis tindak pidana korupsi).

Negara selalu menanggung kerugian negara akibat dari praktik fraud yang terjadi terus menerus. Salah satu fraud yang banyak terjadi di lingkungan pemerintah adalah tindak pidana korupsi. Seperti fenomena yang beredar terkait isu korupsi pengadaan e-KTP yang diduga merugikan negara sebesar kurang lebih Rp2,3 triliun. (detik.com, 27 April 2017). Kasus korupsi sudah banyak yang terungkap dan para pelakunya telah diproses secara hukum, namun belum ada indikasi bahwa tindak korupsi itu akan segera berakhir, justru semakin banyak tindak korupsi yang terungkap dan bahkan pelakunya semakin banyak dan beragam. Berbagai upaya telah dilakukan pemerintah untuk memberantas korupsi, yaitu dengan membentuk Komisi Pemberantasan Korupsi (KPK), meningkatkan peran lembaga penegak hukum, melakukan upaya preventif dan edukatif melalui sosialisasi dan pendidikan anti korupsi, pembentukan Unit Pengendalian Gratifikasi (UPG) dan pembentukan Whistle Blower System (WBS) di masing-masing Instansi Pemerintah, namun semuanya itu masih belum cukup memadai untuk mewujudkan iklim pemerintahan yang bebas dari korupsi.

Suharti dkk, (2015) menyatakan sumber korupsi terbesar dalam sektor keuangan publik adalah pengadaan barang/jasa. Hal ini didukung oleh data yang dirilis Indonesia Procurement Watch (IPW) yang menunjukkan bahwa 70\% kasus korupsi di Indonesia berbentuk penyimpangan pengadaan barang/ jasa Pengadaan barang/jasa menjadi faktor yang sangat rentan terhadap korupsi. Meskipun Pemerintah melalui Keputusan Presiden No. 80 tahun 2013 sebagaimana telah dilakukan beberapa kali perubahan menjadi Peraturan Presiden Nomor 4 tahun 2015 berusaha mengatur agar pelaksanaan proses pengadaan dapat berjalan dengan lebih efektif dan efisien, namun dalam pelaksanaannya masih dijumpai terjadinya fraud. Data KPK memperlihatkan bahwa pengadaan barang/jasa menempati urutan kedua terbesar setelah perkara penyuapan dari seluruh perkara yang ditangani oleh KPK sepanjang tahun 2011 - 2015 seperti ditunjukkan pada grafik 1 . dibawah ini.

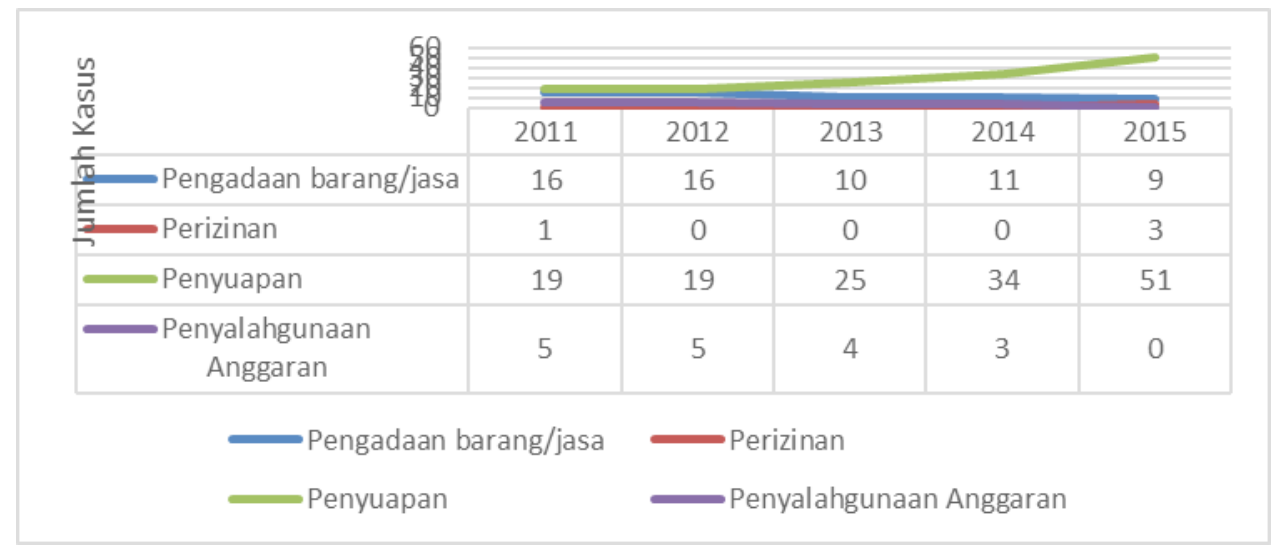

Sumber : Data KPK 2015 (Materi Pengendalian dan Pencegahan Gratifikasi oleh KPK)

Grafik 1. Jenis perkara yang ditangani KPK tahun 2011 - 2015 
Suharti, dkk (2015) menyatakan setiap tahunnya, BPK maupun KPK melaporkan adanya kasus pengadaan yang mengandung unsur tindak pidana korupsi, tetapi tidak banyak yang masuk ke persidangan. Beberapa kasus pengadaan yang berhasil diselesaikan di pengadilan, justru mematahkan legenda bahwa mark up hanya 30\%. Istilah 30\% adalah kebocoran yang terjadi menurut Prof. Dr. Soemitro Djojohadikusumo (Tuanakotta, 2007:279). Padahal, jumlah uang negara yang dikelola melalui proses pengadaan pada tahun 2014 diperkirakan sekitar Rp600 triliun (APBN) dan Rp320 triliun (APBD). Selain itu, menurut catatan IPW, setiap tahunnya ada sekitar 400 ribu paket pekerjaan di 560 kabupaten/kota di seluruh Indonesia. Paket pekerjaan ini belum termasuk paket yang ada di BUMN dan BUMD yang nilainya juga tak sedikit.

Indonesia Corruption Watch (ICW) menyebutkan dari 122 kasus korupsi kesehatan, 43 kasus diantaranya merupakan kasus pengadaan alat kesehatan dengan kerugian negara sebesar Rp. 442,0 milyar. Dari 122 kasus tersebut sebagian besar diantaranya bermodus penggelembungan harga barang/jasa. Hal ini bisa dimaklumi karena kasus yang ditindak umumnya adalah kasus korupsi pengadaan alat kesehatan, obat dan pembangunan/rehabilitasi rumah sakit dan puskesmas (Sindonews.com, 26 Januari 2015).

Beberapa peneliti telah melakukan penelitian terkait faktor-faktor yang mempengaruhi terjadinya fraud. Hasil penelitian menunjukkan inkonsistensi terhadap faktorfaktor yang memperngaruhi terjadinya fraud. World Bank (2001), menemukan bahwa ketidakmampuan personil yang terkait dengan kegiatan pengadaan barang/jasa sebagai salah satu penyebab belum berfungsinya sistem pengadaan barang/jasa secara baik di Indonesia. Sartono (2006), hasil penelitiannya menunjukkan adanya pengaruh kualitas panitia pengadaan barang/jasa terhadap terjadinya fraud pengadaan barang/jasa baik dari sudut pandang internal maupun eksternal instansi. Gelderman, Ghijsen dan Brugman (2006), menunjukkan bahwa pemahaman pejabat pengadaan terhadap peraturan berpengaruh signifikan dan positif terhadap ketaatan peraturan, sehingga mencegah terjadinya penyimpangan. Jatiningtyas dan Kiswara (2011), dalam hasil penelitian menunjukkan adanya perbedaan hasil penelitian untuk pengaruh kualitas panitia pengadaan terhadap terjadinya fraud pengadaan barang/ jasa yang ditinjau dari sudut pandang responden panitia pengadaan dan responden auditor BPKP. Hasil penelitian dengan responden panitia pengadaan menunjukkan bahwa kualitas panitia pengadaan tidak berpengaruh terhadap terjadinya fraud pengadaan barang/jasa, sebaliknya hasil penelitian dengan responden auditor BPKP menunjukkan bahwa kualitas panitia pengadaan berpengaruh secara negatif dan signifikan terhadap terjadinya fraud pengadaan Arifianti, dkk (2015), membuktikan bahwa integritas dan kompetensi pokja ULP/pejabat pengadaan berimplikasi positif untuk menekan terjadinya fraud.

Rijkckeghem dan Weder (1997), hasil penelitiannya menunjukkan adanya hubungan yang negatif dan signifikan antara penghasilan aparatur pemerintah dengan tingkat korupsi. Wilopo (2006), hasil penelitiannya membuktikan bahwa kesesuaian kompensasi memberikan pengaruh tidak signifikan terhadap perilaku tidak etis dan kecurangan akuntansi. Sulistiyowati (2007), menemukan bahwa secara parsial kepuasan gaji tidak berpengaruh terhadap persepsi aparatur pemerintah daerah tentang tindak pidana korupsi. Thoyibatun (2009), hasil penelitiaannya menunjukkan bahwa kesesuaian sistem kompensasi berpengaruh negatif terhadap kecenderungan kecurangan akuntansi. Aji (2013), menemukan bukti bahwa ada pengaruh yang negatif dan signifikan dalam penilaian penghasilan panitia pengadaan terhadap penyimpangan dalam pengadaan barang/jasa pemerintah. Arifianti, dkk (2015), mengungkapkan bahwa kebijakan pemberian 
kompensasi belum mampu berkontribusi untuk menekan terjadinya fraud.

Sartono (2006), hasil penelitian menunjukkan adanya pengaruh sistem dan prosedur pengadaan barang/jasa terhadap terjadinya fraud pengadaan barang/jasa dari sudut pandang eksternal instansi. Jatiningtyas dan Kiswara (2011), hasil penelitian menunjukkan adanya perbedaan hasil penelitian untuk pengaruh sistem dan prosedur pengadaan terhadap terjadinya fraud pengadaan barang/jasa yang ditinjau dari sudut pandang responden panitia pengadaan dan responden auditor BPKP. Hasil penelitian dengan responden panitia pengadaan menunjukkan bahwa sistem dan prosedur pengadaan tidak berpengaruh terhadap terjadinya fraud pengadaan barang/jasa, sebaliknya hasil penelitian dengan responden auditor BPKP menunjukkan bahwa sistem dan prosedur pengadaan berpengaruh secara negatif dan signifikan terhadap terjadinya fraud pengadaan

Sartono (2006), hasil penelitiannya menunjukkan adanya perbedaan hasil penelitian untuk pengaruh etika pengadaan terhadap terjadinya fraud pengadaan barang/jasa yang ditinjau dari sudut pandang responden panitia pengadaan dan responden auditor BPKP. Hasil penelitian dengan responden panitia pengadaan menunjukkan bahwa etika pengadaan tidak berpengaruh terhadap terjadinya fraud pengadaan barang/ jasa, sebaliknya hasil penelitian dengan responden auditor BPKP menunjukkan bahwa etika pengadaan berpengaruh secara negatif dan signifikan terhadap terjadinya fraud pengadaan. Jatiningtyas dan Kiswara (2011), menemukan hasil yang berbeda antara pengaruh etika pengadaan terhadap terjadinya fraud pengadaan barang/jasa ketika responden berasal dari kelompok yang berbeda. Responden dari internal menyatakan etika pengadaan tidak berpengaruh terhadap terjadinya fraud pengadaan barang/ jasa, sebaliknya hasil penelitian dengan responden auditor BPKP menunjukkan bahwa etika pengadaan berpengaruh secara negatif dan signifikan terhadap terjadinya fraud pengadaan.
Aji (2013), menemukan bukti bahwa ada pengaruh yang negatif dan signifikan dalam etika pengadaan terhadap penyimpangan dalam pengadaan barang/jasa pemerintah.

Sartono (2006), hasil penelitian menunjukkan adanya perbedaan hasil penelitian untuk pengaruh sistem pengendalian internal terhadap terjadinya fraud pengadaan barang/jasa. Hasil penelitian dengan responden panitia pengadaan menunjukkan bahwa sistem pengendalian internal tidak berpengaruh terhadap terjadinya fraud pengadaan barang/jasa, sebaliknya dengan responden auditor BPKP menunjukkan bahwa sistem pengendalian internal berpengaruh secara negatif dan signifikan terhadap terjadinya fraud pengadaan. Thoyibatun (2009), hasil penelitiannya kesesuaian sistem pengendalian internal berpengaruh negatif terhadap kecenderungan akuntansi. Jatiningtyas dan Kiswara (2011), menemukan hasil yang berbeda dalam penelitiannya. Responden dari internal menyatakan pengendalian internal tidak berpengaruh terhadap terjadinya fraud pengadaan barang/jasa, sebaliknya responden auditor BPKP menunjukkan bahwa pengendalian internal berpengaruh secara negatif dan signifikan terhadap terjadinya fraud pengadaan. Arifianti, dkk (2015), membuktikan bahwa sistem pengendalian internal yang baik berimplikasi positif untuk menekan terjadinya fraud.

\section{Telaah Teori dan Pengembangan Hipotesis}

The Association of Certified Fraud Examiners (ACFE) atau Asosiasi Pemeriksa Kecurangan Bersertifikat merupakan organisasi profesional yang bergerak di bidang pemeriksaan atas kecurangan yang berkedudukan di Amerika Serikat. Organisasi ini mengklasifikasikan fraud (kecurangan) dalam hubungan kerja beserta ranting dan anak rantingnya yang dikenal dengan istilah "Fraud Tree" seperti dapat dilihat pada gambar 1. (Priantara, 2013). Adapun ketiga jenis fraud berdasarkan perbuatan itu adalah: 
1. Penyalahgunaan atas asset (Asset Misappropriation)

Asset misappropriation meliputi penyalahgunaan/pencurian aset atau harta perusahaan atau pihak lain. Fraud jenis ini merupakan bentuk fraud yang paling mudah dideteksi karena sifatnya yang tangible atau dapat diukur/dihitung (defined value).

2. Pernyataan palsu atau pelaporan yang dibuat salah (Fraudulent Statement)

Fraudulent statement seringkali diidentikan sebagai management fraud atau fraud yang dilakukan oleh manajemen karena mayoritas pelaku berada pada tingkat manajerial. Fraud jenis ini meliputi tindakan yang dilakukan oleh pejabat atau eksekutif suatu perusahaan atau instansi pemerintah untuk menutupi kondisi keuangan yang sebenarnya dengan melakukan rekayasa keuangan (financial engineering) dalam penyajian laporan keuangannya untuk memperoleh keuntungan atau mungkin dapat dianalogikan dengan istilah window dressing.

Jenis kecurangan fraudulent Statement berkenaan dengan penyajian laporan keuangan sangat menjadi perhatian auditor, masyarakat, atau para LSM, namun tidak menjadi perhatian akuntan forensik. Fraud dalam menyusun laporan keuangan dapat berupa salah saji (misstatement baik overstatement maupun understatement).

3. Korupsi (Corruption)

Korupsi merupakan jenis fraud yang paling sulit dideteksi karena menyangkut kerja sama dengan pihak lain. Fraud jenis ini banyak terjadi di negara-negara berkembang yang penegakan hukumnya masih lemah dan kurang kesadaran akan tata kelola yang baik sehingga faktor integritasnya masih dipertanyakan. Korupsi sering kali tidak dapat dideteksi karena para pihak yang bekerja sama menikmati keuntungan (simbiosis mutualisme). Termasuk dalam fraud ini adalah penyalahgunaan wewenang/konflik kepentingan (conflict of interest), penyuapan (bribery), penerimaan yang tidak sah/illegal (illegal gratuities), dan pemerasan secara ekonomi (economic extortion). 


\section{Uniform Occupational Fraud Classification System}

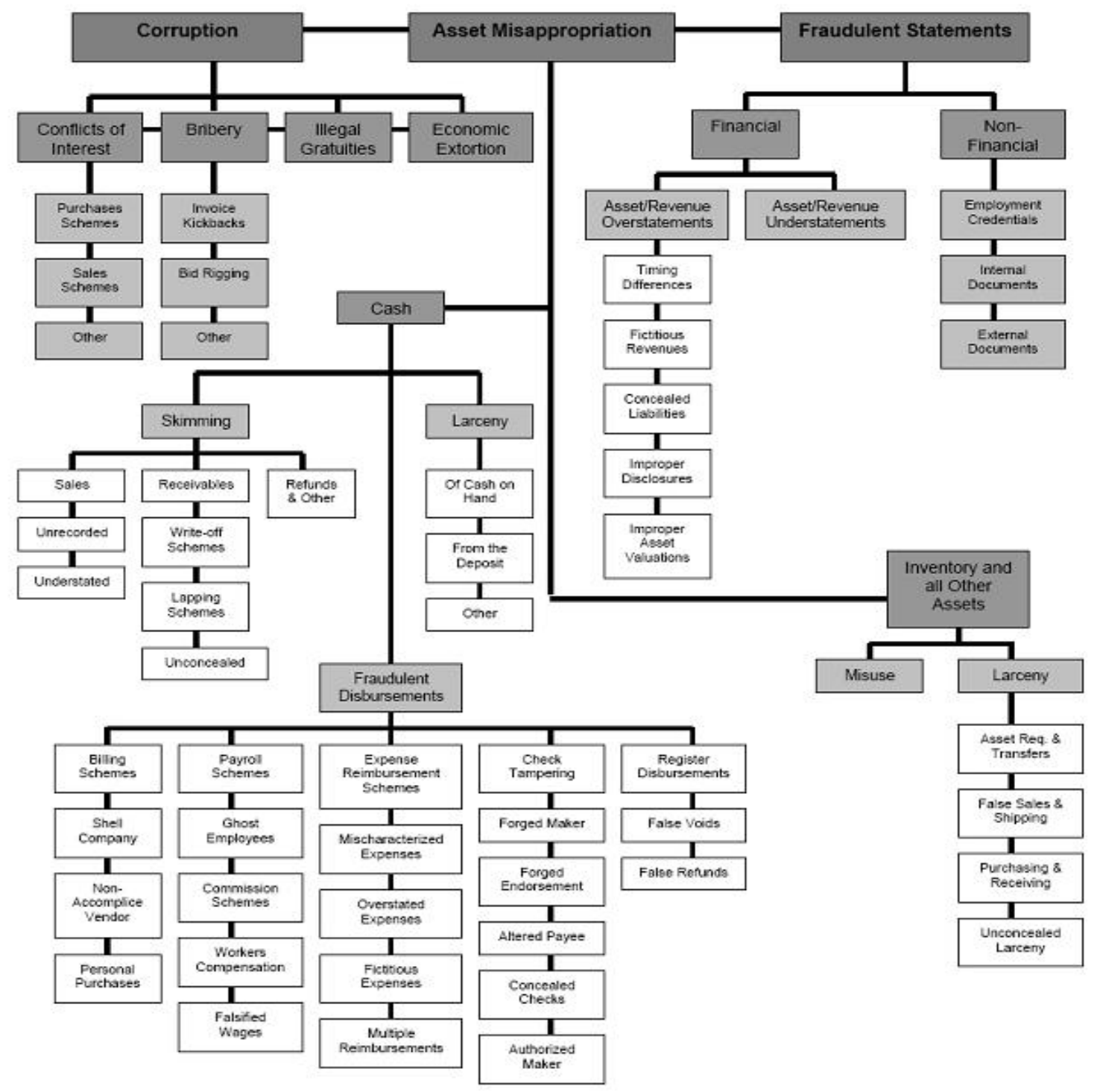

Sumber: Priantara (2013:68), The Association of Certified Fraud Examiners (ACFE)

Gambar 1. Fraud Tree

\section{Pengaruh Kualitas Panitia Pengadaan} Terhadap Fraud Pengadaan Barang/Jasa

Thai (2001) mengungkapkan bahwa profesionalisme atau kualitas panitia pengadaan merupakan faktor yang ikut mempengaruhi keberhasilan suatu sistem pengadaan dalam mencapai tujuan yang telah ditetapkan. Dalam laporan yang dibuatnya World Bank mengungkapkan bahwa salah satu faktor yang menyebabkan belum berfungsinya sistem pengadaan pemerintah di Indonesia antara lain adalah kurangnya kemampuan sebagian besar staf operasional, anggota panitia lelang dan pihak-pihak berwenang yang memberi otorisasi dalam kegiatan pengadaan (World Bank 2001).

World Bank (2001), menemukan bahwa ketidakmampuan personil yang terkait dengan kegiatan pengadaan barang/jasa sebagai salah satu penyebab belum berfungsinya sistem pengadaan barang/jasa secara baik di Indonesia. Sartono (2006), hasil penelitiannya menunjukkan adanya pengaruh kualitas panitia pengadaan barang/jasa terhadap terjadinya fraud pengadaan barang/jasa baik dari sudut pandang 
internal maupun eksternal instansi. Gelderman, Ghijsen dan Brugman (2006), menunjukkan bahwa pemahaman pejabat pengadaan terhadap peraturan berpengaruh signifikan dan positif terhadap ketaatan peraturan, sehingga mencegah terjadinya penyimpangan. Arifianti, dkk (2015), membuktikan bahwa integritas dan kompetensi pokja ULP/pejabat pengadaan berimplikasi positif untuk menekan terjadinya fraud.

$\mathrm{H}_{1}$ : Kualitas panitia pengadaan ber-pengaruh terhadap fraud pengadaan barang/jasa

\section{Pengaruh Penghasilan Panitia Penga-daan Terhadap Fraud Pengadaan Barang/Jasa}

Selain aspek kualitas panitia pengadaan, aspek lain yang perlu diperhatikan dalam mewujudkan proses pengadaan yang obyektif adalah penghasilan Panitia Pengadaan. Personil panitia pengadaan merupakan bagian dari aparatur pemerintah dan mendapatkan penghasilan sebagai pegawai negeri berdasarkan peraturan yang berlaku ditambah dengan honorarium sebagai panitia pengadaan.

Upaya mencari tambahan penghasilan ini mungkin saja dilakukan dengan segala cara termasuk dengan memanfaatkan jabatan dan kewenangan yang dimiliki. Misalnya personil Panitia Pengadaan 'mengatur" jalannya proses pengadaan untuk memenangkan salah satu peseta pengadaan dengan meminta imbalan sejumlah uang tertentu.

Konsep keadilan internal dan keadilan eksternal merupakan hal yang sangat diperhatikan dalam sektor swasta. Keadilan internal terutama ditujukan untuk menjaga motivasi kerja, sedangkan konsep keadilan terutama ditujukan untuk "menahan" terjadinya perpindahan pegawai ke perusahaan lain.

Untuk sektor pemerintah, konsep keadilan internal dan keadilan eksternal dalam hal pemberian gaji (kompensasi) seharusnya juga diterapkan. Baik konsep keadilan keadilan internal maupun keadilan eksternal bisa dijadikan sebagai salah satu strategi untuk mengurangi tingkat penyimpangan yang terjadi. Hal ini beranjak dari pemikiran bahwa penyimpangan biasanya dimulai karena adanya ketidakseimbangan antara penghasilan dengan kebutuhan hidup yang wajar.

Penyimpangan yang semula hanya dilakukan untuk mencukupi kebutuhan hidup yang wajar, lambat laun berkembang menjadi lebih buruk dan mengarah kepada keserakahan dan sifat tamak. Penyimpangan yang semula mungkin hanya berdampak kerugian negara dalam jumlah kecil, selanjutnya akan bertambah menjadi penyimpangan yang berdampak pada kerugian negara yang sangat besar. Dengan diterapkannya konsep keadilan internal maupun keadilan eksternal, diharapkan tidak ada lagi pemicu untuk "dimulainya" suatu penyimpangan yang pada akhirnya akan menekan dan mengurangi tingkat penyimpangan yang terjadi.

Rijkckeghem dan Weder (1997), hasil penelitiannya menunjukkan adanya hubungan yang negatif dan signifikan antara penghasilan aparatur pemerintah dengan tingkat korupsi. Wilopo (2006), hasil penelitiannya membuktikan bahwa kesesuaian kompensasi memberikan pengaruh tidak signifikan terhadap perilaku tidak etis dan kecurangan akuntansi. Sulistiyowati (2007), menemukan bahwa secara parsial kepuasan gaji tidak ber-pengaruh terhadap persepsi aparatur pemerintah daerah tentang tindak pidana korupsi. Thoyibatun (2009), hasil penelitiaannya menunjukkan bahwa kesesuaian sistem kompensasi berpengaruh negatif terhadap kecenderungan kecurangan akuntansi. Aji (2013), menemukan bukti bahwa ada pengaruh yang negatif dan signifikan dalam penilaian penghasilan panitia pengadaan terhadap penyimpangan dalam pengadaan barang/jasa pemerintah. Arifianti, dkk (2015), mengungkapkan bahwa kebijakan pemberian kompensasi belum mampu berkontribusi untuk menekan terjadinya fraud.

$\mathrm{H}_{2}$ : Penghasilan panitia pengadaan berpengaruh terhadap fraud pengadaan barang/jasa 


\section{Pengaruh Sistem dan Prosedur Penga-daan Terhadap Fraud Pengadaan Barang/Jasa}

Aspek lain yang ikut menentukan jalannya sistem pengadaan adalah ketentuan dan prosedur pengadaan barang/jasa itu sendiri. Ketentuan dan prosedur pengadaan juga berpengaruh terhadap keberhasilan suatu sistem pengadaan pemerintah dalam men-capai tujuan yang telah ditetapkan (Thai, 2001).

Sistem dan prosedur pengadaan pemerintah yang baik (Jourdain dan Balgobin, 2003) memiliki beberapa karakteristik antara lain:

\section{Transparency \\ 2. Economy \\ 3. Efficiendy and timeliness \\ 4. Fairness and equity}

Dari rangkuman berbagai literatur, terdapat beberapa karakteristik suatu sistem dan prosedur pengadaan pemerintah yang baik, yaitu:

1. Memiliki landasan hukum yang jelas dan transparan.

Landasan hukum dari sistem dan pro-sedur yang berlaku harus cukup kuat sehingga upaya penegakan ketentuan yang diaturnya bisa dilakukan secara efektif (World Bank 2001)

Transparansi suatu peraturan merupa-kan hal yang sangat penting untuk menciptakan suatu peraturan yang mampu mendorong kompetisi, per-dagangan dan investasi serta mencegah ditumpangi oleh kepentingan pihak tertentu( OECD, 2002).

2. Dapat dimengerti (understandable) oleh pihak-pihak yang berkepentingan.

Sistem dan prosedur pengadaan pemerintah seharusnya mudah didapat dan dipahami oleh pihak-pihak yang berkepentingan. Hal ini bisa dicapai dengan melakukan kodifikasi dan publikasi yang memadai atas berbagai peraturan/ketentuan yang diterbitkan (OECD, 2002)

3. Dapat diterapkan (applicable).

Sistem dan prosedur pengadaan pemerintah tidak boleh mengatur hal-hal yang tidak dapat diimplementasikan di lapangan. Salah satu penyebab tidak dapat diterapkannya sistem dan prosedur di lapangan adalah adanya kesimpangsiuran, ketidakjelasan inter-pretasi atas ketentuan sebagai akibat tumpang tindihnya berbagai peraturan mengatur berbagai aspek pengadaan pemerintah (World Bank 2001).

4. Mendorong terciptanya kompetisi secara fair.

Sistem dan prosedur pengadaan seharusnya mendorong untuk terjadinya kompetisi secara sehat. Rose-Ackerman (1996) dalam Celentani dan Ganuza (2001) menyatakan bahwa secara umum, perubahan yang bertujuan mendorong kompetisi dalam suatu perekonomian akan membantu mengurangi dorongan untuk melakukan korupsi.

5. Menyediakan mekanisme feedback dan complaint apabila terjadi ketidaktaatan pada ketentuan yang telah digariskan.

Sistem dan prosedur pengadaan juga harus memiliki mekanisme feedback sehingga memungkinkan upaya perbaikan dan penyempurnaan yang diperlukan. Mekanisme complaint juga perlu diciptakan untuk memperkuat upaya untuk dipatuhinya ketentuan yang digariskan. World Bank mengungkapkan bahwa salah satu penyebab belum berfungsinya sistem pengadaan di Indonesia secara baik adalah kurangnya tindak lanjut terhadap berbagai protes dalam proses pengadaan dan tidak adanya pemantauan yang sistematik terhadap kepatuhan atas peraturan dan prosedur pengadaan (Word Bank, 2001).

Sartono (2006), hasil penelitian menunjukkan adanya pengaruh sistem dan prosedur pengadaan barang/jasa terhadap terjadinya fraud pengadaan barang/jasa dari sudut pandang eksternal instansi. Jatiningtyas dan Kiswara (2011), hasil penelitian menunjukkan pengaruh sistem dan prosedur pengadaan terhadap terjadinya fraud pengadaan barang/ jasa yang ditinjau dari sudut pandang responden auditor BPKP. 
$\mathrm{H}_{3}$ : Sistem dan Prosedur Pengadaan berpengaruh terhadap fraud pengadaan barang/jasa.

\section{Pengaruh Etika Pengadaan Terhadap Fraud Pengadaan Barang/Jasa}

Etika pengadaan juga merupakan salah satu aspek penting yang perlu diperhatikan untuk terciptanya pengadaan pemerintah yang sehat. Etika pengadaan berkaitan dengan kelaziman dalam praktek dunia usaha yang dianggap akan menciptakan sistem persaingan usaha yang adil. Etika dalam pengadaan akan mencegah penyalahgunaan wewenang atau kolusi untuk keuntungan pribadi atau golongan yang secara langsung atau tidak dapat merugikan negara.

Dalam kegiatan pengadaan pemerintah, beberapa praktek yang tidak sehat yang perlu dihilangkan antara lain:

1. Pemberian imbalan/hadiah kepada panitia pengadaan atau pejabat pada intansi yang menyelenggarakan kegia-tan pengadaan.

2. Adanya peserta pengadaan yang tidak memiliki kompetensi dan kemampuan untuk melaksanakan pekerjaan (peserta pengadaan hanya bertindak sebagai calo).

3. Pemberian discount (potongan harga) yang dilakukan secara tersembunyi yang diberikan kepada oknum panitia pengadaan ataupun pejabat pada ins-tansi yang menyelenggarakan kegiatan pengadaan .

Sartono (2006), hasil penelitiannya menunjukkan adanya pengaruh etika pengadaan terhadap terjadinya fraud pengadaan barang/ jasa yang ditinjau dari sudut pandang responden auditor BPKP. Jatiningtyas dan Kiswara (2011), menemukan hasil bahwa etika pengadaan berpengaruh secara negatif dan signifikan terhadap terjadinya fraud pengadaan dengan responden auditor BPKP. Aji (2013), menemukan bukti bahwa ada pengaruh yang negatif dan signifikan dalam etika pengadaan terhadap penyimpangan dalam pengadaan barang/jasa pemerintah.
$\mathrm{H}_{4}$ : Etika Pengadaan berpengaruh terhadap fraud pengadaan barang/jasa.

\section{Pengaruh Sistem Pengendalian Internal Terhadap Fraud Pengadaan Barang/Jasa}

Menurut pasal 1 butir 1 Peraturan Pemerintah Republik Indonesia Nomor 60 Tahun 2008 yang dimaksud dengan sistem pengendalian intern adalah proses yang integral pada tindakan dan kegiatan yang dilakukan secara terus menerus oleh pimpinan dan seluruh pegawai untuk memberikan keyakinan memadai atas tercapainya tujuan organisasi melalui kegiatan yang efektif dan efisien, keandalan pelaporan keuangan, pengamanan aset negara, dan ketaatan terhadap peraturan perundangundangan.

Lebih lanjut pada pasal 3 dijelaskan bahwa sistem pengendalian intern terdiri atas unsur lingkungan pengendalian, penilaian resiko, kegiatan pengendalian, informasi dan komunikasi dan pemantauan. Penerapan Sistem Pengendalian Internal yang baik diyakini mampu untuk menekan terjadinya tindak kecurangan. Dalam pengadaan barang dan jasa Sistem Pengendalian Internal dapat diterapkan mulai dari perencanaan pengadaan sampai dengan pelaksanaan pengadaan sehingga tindakan tersebut dapat menurunkan potensi terjadinya fraud dalam kegiatan pengadaan barang/ jasa.

Sartono (2006), hasil penelitian menunjukkan sistem pengendalian internal berpengaruh secara negatif dan signifikan terhadap terjadinya fraud pengadaan. Thoyibatun (2009), hasil penelitiannya menunjukkan kesesuaian sistem pengendalian internal berpengaruh negatif terhadap kecenderungan akuntansi. Jatiningtyas dan Kiswara (2011), menemukan hasil bahwa pengendalian internal berpengaruh secara negatif dan signifikan terhadap terjadinya fraud pengadaan dengan responden auditor BPKP. Arifianti, dkk (2015), membuktikan bahwa sistem pengendalian 
internal yang baik berimplikasi positif untuk menekan terjadinya fraud.

$\mathrm{H}_{5}$ : Etika Pengadaan berpengaruh terhadap fraud pengadaan barang/jasa

\section{Metode}

Populasi dalam penelitian ini adalah seluruh auditor di Inspektorat Jenderal Kementerian Kesehatan yang telah mempunyai pengalaman minimal satu tahun dalam melakukan audit pengadaan barang/jasa. Jumlah populasi seluruhnya sebanyak 129 orang dengan klasifikasi jabatan auditor utama, auditor madya, auditor muda, auditor pertama. Penentuan jumlah sampel yang diambil menggunakan rumus Slovin dengan margin/sampling error sebesar 10\% (Mulyanto dan Wulandari, 2010:103) sehingga diperoleh sebanyak 56 responden. Metode pengumpulan data dengan menggunakan kuisioner, wawancara dan telaah dokumen.

Fraud pengadaan barang/jasa dalam penelitian ini adalah seberapa jauh penilaian responden terhadap tingkat penyimpangan yang terjadi dalam kegiatan pengadaan barang/ jasa pemerintah terutama yang berakibat pada kerugian keuangan negara. Kualitas Panitia Pengadaan adalah sejumlah penilaian responden terhadap kualitas personel Panitia Pengadaan dilihat dari beberapa indikator, yaitu tingkat integritas, kompetensi, independensi dan obyektifitas yang dimiliki oleh Personel Panitia Pengadaan barang/jasa dalam menjalankan tugasnya. Penghasilan Panitia Pengadaan dalam penelitian ini adalah tingkat kelayakan penghasilan sah (resmi) yang diterima oleh Panitia Pengadaan barang/jasa menurut penilaian responden. Penilaian dilakukan dengan menekankan pada beberapa dimensi, yaitu keadilan internal, keadilan eksternal dan juga seberapa besar penghasilan yang diterima telah memberikan insentif kepada Panitia Pengadaan untuk tidak menyalahgunakan jabatan dan kewenangan yang dimiliki.
Sistem dan Prosedur Pengadaan dalam penelitian ini adalah seberapa baik sistem dan prosedur pengadaan barang/jasa yang berlaku pada saat ini menurut penilaian responden. Penilaian dilakukan dengan memperhatikan beberapa indikator, yaitu: kejelasan landasan hukum, tingkat kesulitan bagi subyek pengadaan untuk memahami ketentuan, tingkat kesulitan penerapan ketentuan di lapangan, insentif untuk terciptanya kompetisi yang sehat, serta seberapa baik mekanisme pengaduan yang telah diatur dalam ketentuan tersebut. Etika Pengadaan dalam penelitian ini adalah sejauhmana penilaian responden terhadap terciptanya praktek pengadaan barang/jasa yang sehat di lapangan. Penilaian dilakukan dengan melihat seberapa banyak praktek bisnis yang sehat telah tercipta yang diharapkan akan memperkecil peluang untuk terjadinya penyimpangan dalam pengadaan barang/jasa. Sistem Pengendalian Internal adalah penilaian responden terhadap penerapan SPI dalam proses pengadaan yang menurut Mulyadi (2002), COSO dalam Arens (2008) dan Sawyer (2003) terdiri dari Lingkungan Pengendalian, Penilaian Resiko, Kegiatan Pengendalian, Informasi dan Komunikasi dan Pemantauan.

Instrumen yang digunakan dalam penelitian ini mengacu pada penelitian Sartono (2006) Penilaian dilakukan dengan memberikan tingkat persetujuan ataupun ketidaksetujuan responden terhadap pernyataan tersebut dengan menggunakan 5 skala likert dari skala 1 (sangat tidak setuju) sampai dengan 5 (sangat setuju). Sebelum digunakan sebagai instrumen penelitian, maka dilakukan uji validitas dan uji reliabilitas. Validitas menunjukkan seberapa nyata suatu pengujian mengukur apa yang seharusnya diukur. Validitas berhubungan dengan ketepatan alat ukur, kenyataan (actually) dan tujuan dari pengukuran. Sementara reliabilitas adalah kemampuan alat ukur untuk mengukur berkali-kali dan menghasilkan data yang sama (Mulyanto dan Wulandari, 2010:97). Pernyataan valid apabila nilai korelasi (kolom Corrected 
Item-Total Correction) $>$ 0,3 (Mulyanto dan Wulandari, 2010:125)., reliabilitas terpenuhi manakala nilai Cronbac' $h$ Alpha $>0,6$ (Mulyanto dan Wulandari, 2010:126).

Pengujian awal harus dilakukan terhadap data penelitian sebelum dilakukan uji statistik lebih lanjut, yaitu dengan melakukan uji asumsi klasik yang terdiri dari uji normalitas, uji multikolinieritas dan uji heteroskedastisitas. Uji normalitas bertujuan untuk menguji apakah dalam model regresi, variabel pengganggu atau residual memiliki distribusi normal, uji normalitas dibuktikan melalui One-Sample Kolmogorov-Smirnov Test, jika signifikan $>\alpha$, maka data variabel berdistribusi normal. Untuk lebih memperjelas sebaran data dalam penelitian ini maka akan disajikan grafik normal $P$-Plot. Uji multikolinieritas bertujuan untuk menguji apakah dalam model regresi ditemukan adanya korelasi antar variabel bebas (independen), metode deteksi yaitu dengan melihat nilai tolerance dan Variance Inflation Factor (VIF). Apabila tidak ada variabel independen yang memiliki nilai tolerance $<0,10$ atau nilai $\mathrm{VIF}>10$, maka dalam model regresi tidak terdapat multikolinieritas (Ghozali, 2013:106). Uji heteroskedastisitas bertujuan menguji apakah dalam model regresi terjadi ketidaksamaan variance dan residual satu pengamatan ke pengamatan yang lain. Jika variance dari residual satu pengamatan ke pengamatan yang lain tetap, maka disebut homoskedastisitas dan jika berbeda disebut heteroskedastisitas. Model regresi yang baik adalah yang homoskedastisitas atau tidak terjadi heteroskesdastisitas, cara mendeteksi dengan Uji Glejser dengan probabilitas signifikannya di atas tingkat kepercayaan 5\%, maka dapat disimpulkan model regresi tidak mengandung Heteroskedastisitas.

Pengujian hipoesis dalam penelitian ini menggunakan uji regresi berganda. Uji koefsien determinasi dan uji $\mathrm{F}$ digunakan untuk menguji model penelitian (goodness of fit model), Uji $\mathrm{t}$ digunakan untuk menguji pengaruh masinmasing variabel independen terhadap variabel dependennya. Hipotesis penelitian dikatakan terbukti jika hasil pengujian menunjukkan nilai siginifikansi $<0,05$ artinya ada pengaruh signifikan antara variabel independen dengan variabel dependen.

\section{Hasil Penelitian dan Pembahasan}

Uji validitas menunjukkan nilai korelasi skor item dengan skor total untuk semua pertanyaan $>0,3$ maka seluruh item pernyataan kuisioner untuk seluruh variabel dinyatakan valid. Hasil uji relibilitas menunjukkan nilai cronbach alpha untuk seluruh variabel > 0,6 sehingga dapat disimpulkan bahwa seluruh item adalah reliable (andal). Hasil uji normalitas menunjukkan bahwa data terdistribusi normal, terlihat dari nilai Kolmogorov-Smirnov $Z$ sebesar 0,562 dan signifikan pada angka 0,911 berada di atas batas erorr yaitu 0,5 sehingga dapat disimpulkan data terdistribusi normal. Hasil uji multikolinieritas menunjukkan bahwa variabel-variabel bebas dalam penelitian tidak menunjukkan nilai tolerance kurang dari 1,0. Demikian juga dengan hasil perhitungan Variance Inflation Factor (VIF) tidak ada yang nilainya kurang dari 10 sehingga dapat disimpulkan tidak ada multikolinieritas antar variabel bebas dalam model regresi ini. Hasil uji heteroskedastisitas menggunakan Uji Glejser diperoleh nilai signifikansi sebesar 1,000 menurut Gujarati dalam Ghozali (2013:142), hasil penelitian variabel dependen nilai absolut residual (AbsRes) terhadap variabel independen dengan probabilitas signifikannya di atas tingkat kepercayaan 5\%, maka dapat disimpulkan model regresi tidak mengandung Heteroskedastisitas

Pengujian hipotesis dalam penelitian dilakukan dengan Uji regresi linier berganda. Berdasarkan hasil olah data dengan menggunakan SPSS diperoleh hasil seperti pada Tabel 1. 
Tabel 1. Hasil Pengujian Hipotesis

\begin{tabular}{lcccc}
\hline \multicolumn{1}{c}{ Variabel Independen } & B & Std. Error & t hitung & Sig. \\
\hline Kualitas Panitia Pengadaan & -.279 & .107 & -2.609 & .012 \\
Penghasilan Panitia Pengadaan & -.023 & .050 & -.466 & .643 \\
Sistem dan Prosedur Pengadaan & -.215 & .075 & -2.886 & .006 \\
Etika Pengadaan & -.258 & .075 & -3.458 & .001 \\
Sistem Pengendalian Internal & -.330 & .128 & -2.577 & .013 \\
Constant & 6.291 & .156 & 40.268 & .000 \\
R Square & .935 & & & \\
Adjusted R Square & .928 & & & \\
F hitung & 142.746 & & & \\
Sig. F & $.000^{\mathrm{b}}$ & & & \\
\hline
\end{tabular}

Berdasarkan hasil analisa regresi berganda tersebut dapat dibentuk persamaan regresi linear berganda sebagai berikut:

$$
\begin{aligned}
\mathrm{Y}= & 6,291-0,279 \times 1-0,023 \times 2-0,215 \times 3 \\
& -0,258 \times 4-0,330 \times 5+e
\end{aligned}
$$

Berdasarkan tabel di atas diketahui nilai adjusted $\mathrm{R}^{2}$ sebesar 0,928 , artinya ada hubungan yang sangat tinggi antara variabel bebas Kualitas Panitia Pengadaan, Penghasilan Panitia Pengadaan, Sistem dan Prosedur Pengadaan, Etika Pengadaan dan Sistem Pengendalian Internal terhadap variabel terikat Fraud. Hal ini berarti sebesar 92,8\% variasi Fraud dapat dijelaskan oleh variasi dari kelima variabel bebas, sedangkan sisanya sebesar $(100 \%$ $92,8 \%) 7,2 \%$ dipengaruhi oleh faktor lainnya yang tidak diteliti dalam penelitian ini.

Dari tabel diatas untuk uji $\mathrm{F}$ menunjukkan

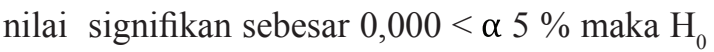
ditolak sehingga dapat disimpulkan bahwa secara simultan ada pengaruh yang signifikan antara Kualitas Panitia Pengadaan, Penghasilan Panitia Pengadaan, Sistem dan Prosedur Pengadaan, Etika Pengadaan dan Sistem Pengendalian Internal secara bersama-sama terhadap Fraud.

Hasil uji $t$ menunjukkan bahwa untuk variabel Kualitas Panitia Pengadaan (X1) diperoleh $\mathrm{p}$ value (sig) sebesar $0,012<\alpha 5 \%$ maka $\mathrm{H}_{0} 1$ ditolak dan menerima $\mathrm{H}_{\mathrm{a}} 1$, artinya Kualitas Panitia Pengadaan (X1) secara parsial mempunyai pengaruh yang signifikan terhadap
Fraud (Y). Variabel Penghasilan Panitia Pengadaan (X2) diperoleh nilai $\mathrm{p}$ value (sig) sebesar $0,643>\alpha 5 \%$ maka $\mathrm{H}_{\mathrm{a}} 1$ ditolak dan menerima $\mathrm{H}_{0} 1$, artinya Penghasilan Panitia Pengadaan (X2) secara parsial tidak mempunyai pengaruh yang signifikan terhadap Fraud (Y). Variabel Sistem dan Prosedur Pengadaan (X3) diperoleh nilai $\mathrm{p}$ value (sig) sebesar $0,006<\alpha 5$ $\%$ maka $\mathrm{H}_{0} 1$ ditolak dan menerima $\mathrm{H}_{\mathrm{a}} 1$, artinya Sistem dan Prosedur Pengadaan (X3) secara parsial mempunyai pengaruh yang signifikan terhadap Fraud (Y). Variabel Etika Pengadaan (X4) diperoleh nilai $\mathrm{p}$ value (sig) sebesar 0,001 $<\alpha 5 \%$ maka $\mathrm{H}_{0} 1$ ditolak dan menerima $\mathrm{H}_{\mathrm{a}} 1$, artinya Etika Pengadaan (X4) secara parsial mempunyai pengaruh yang signifikan terhadap Fraud (Y). Variabel Sistem Pengendalian Internal (X5) diperoleh nilai dengan $\mathrm{p}$ value (sig) sebesar $0,013<\alpha 5 \%$ maka $\mathrm{H}_{0} 1$ ditolak dan menerima $\mathrm{H}_{\mathrm{a}} 1$, artinya Sistem Pengendalian Internal (X5) secara parsial mempunyai pengaruh yang signifikan terhadap Fraud (Y).

\section{Pengaruh Kualitas Panitia Pengadaan Terhadap Fraud Pengadaan Barang/Jasa}

Hasil uji parsial (uji t) menunjukkan bahwa Kualitas Panitia Pengadaan mempunyai pengaruh yang signifikan terhadap fraud pengadaan barang/jasa (Y). Terjadinya fraud pengadaan barang/jasa dapat dikurangi dengan meningkatkan kualitas panita pengadaan. Hasil 
penelitian ini sejalan dengan Sartono (2006), yang menunjukkan adanya pengaruh kualitas panitia penga-daan barang/jasa terhadap terjadinya fraud pengadaan barang dan jasa baik dari sudut pandang internal maupun eksternal instansi. Sementara Gelderman, Ghijsen dan Brugman (2006), menunjukkan bahwa pemahaman pejabat pengadaan terhadap peraturan berpengaruh signifikan dan positif terhadap ketaatan peraturan, sehingga mencegah terjadinya penyimpangan Hasil penelitian ini juga sejalan dengan Jatiningtyas dan Kiswara (2011), yang menunjukkan bahwa kualitas panitia pengadaan berpengaruh secara negatif dan signifikan terhadap terjadinya fraud pengadaan dari sudut pandang responden eksternal. Demikian pula pendapat Arifianti, dkk (2015), membuktikan bahwa integritas dan kompetensi pokja ULP/ pejabat pengadaan berimplikasi positif untuk menekan terjadinya fraud. Hasil penelitian tidak mendukung Jatiningtyas dan Kiswara (2011) yang menunjukkan bahwa kualitas panitia pengadaan tidak berpengaruh secara negatif dan signifikan terhadap terjadinya fraud pengadaan dari sudut pandang responden internal.

Panitia pengadaan merupakan salah satu subyek (pelaku) pengadaan barang/jasa pemerintah dan aktivitas serta keputusan yang dilakukannya akan sangat menentukan jalannya proses pengadaan. Segala aktivitas dan keputusan yang diambil oleh Panitia Pengadaan merupakan hal yang sangat krusial karena berhadapan langsung dengan kepentingan dari berbagai subyek pengadaan barang/jasa lainnya. Untuk itu kemampuan dan profesionalisme personel panitia sangat berpengaruh terhadap terjadinya fraud pengadaan barang dan jasa.

Dalam penelitian ini, profesionalisme atau kualitas Panitia Pengadaan dilihat dari beberapa dimensi yaitu integritas, kompetensi, serta obyektivitas dan independensi. Integritas merupakan hal pertama dan mendasar yang perlu ditekankan dalam setiap subyek (pelaku) suatu sistem, termasuk sistem pengadaan barang/jasa pemerintah karena integritas personil inilah yang akan mewarnai arah berjalannya suatu sistem pengadaan barang/jasa. Integritas yang baik dari panitia pengadaan akan mendorong terlaksananya proses pengadaan yang bersih, bebas korupsi, kolusi dan nepotisme. Hasil penelitian menunjukkan sebagian besar responden berpendapat bahwa kondisi panita pengadaan yang selalu menjunjung tinggi integritas akan menurunkan potensi terjadinya fraud. Kasus fraud yang sering dijumpai di Indonesia diawali dengan panitia pengadaan yang tidak mempunyai integritas sehingga mudah untuk dihasut oleh pihak lain sehingga terjadi perilaku yang menyimpang dalam proses pengadaan.

Mengingat strategisnya posisi Panitia Pengadaan, maka diperlukan kompetensi minimal untuk bisa menjabat sebagai Panitia Pengadaan. Tuntutan kompetensi minimal antara lain pemahaman mengenai sistem dan prosedur pengadaan serta pemahaman yang cukup memadai mengenai barang/jasa yang akan diadakan. Hasil penelitian menunjukkan sebagian besar responden berpendapat bahwa kompetensi yang dimiliki panitia pengadaan akan menurunkan potensi terjadinya fraud. Dengan kompetensi yang memadai permasalahan didalam pengadaan seperti barang yang tidak sesuai spesifikasi, kekurangan volume dan keterlambatan barang bisa dihindari atau dikurangi.

Proses pengadaan barang/jasa pemerintah merupakan proses yang penuh dengan berbagai muatan kepentingan masing-masing subyek pengadaan barang/jasa. Untuk itu seluruh proses pengadaan barang/jasa haruslah berjalan secara obyektif dan independen (Jourdain dan Balgobin, 2003). Untuk mewujudkan hal ini Panitia Pengadaan sebagai personil yang menyelenggarakan proses ini harus mengedepankan prinsip obyektifitas dan ketidakberpihakan kepada kepentingan salah satu atau sekelompok peserta proses pengadaan barang/jasa. Hasil penelitian menunjukkan sebagian besar responden berpendapat bahwa 
kondisi panita pengadaan yang selalu menjunjung tinggi Obyektifitas dan Independensi akan menurunkan potensi terjadinya fraud. Dengan bersikap obyektif dan independen pelaksanaan pengadaan akan berjalan dengan baik. Banyak kasus pengadaan berupa pembelian barang yang sebenarnya tidak sesuai dengan kebutuhan instansi/masyarakat, hal ini disebabkan panitia pengadaan tidak obyektif dan independen. Panitia berpihak terhadap salah satu pemegang kepentingan yang telah menjanji-kan hadiah/ pemberian, sehingga barang yang dibeli bukan yang dibutuhkan oleh instansi/masyarakat.

\section{Pengaruh Penghasilan Panitia Pengadaan Terhadap Terjadinya Fraud Pengadaan Barang/Jasa}

Hasil uji parsial (uji t) menunjukkan bahwa Penghasilan Panitia Pengadaan tidak mempunyai pengaruh yang signifikan terhadap fraud pengadaan barang/jasa (Y). Terjadinya fraud pengadaan barang/jasa tidak dapat diyakini berkurang dengan penghasilan panitia pengadaan yang meningkat. Hasil penelitian ini konsisten dengan penelitian yang dilakukan oleh Wilopo (2006), yang membuktikan bahwa kesesuaian kompensasi memberikan pengaruh tidak signifikan terhadap perilaku tidak etis dan kecurangan akun-tansi. Sementara Sulistiyowati (2007), menemukan bahwa secara parsial kepuasan gaji tidak berpengaruh terhadap persepsi aparatur pemerintah daerah tentang tindak pidana korupsi. Demikian dengan Arifianti, dkk (2015), yang mengungkapkan bahwa kebijakan pemberian kompensasi belum mampu berkontribusi untuk menekan terjadinya fraud.

Hasil penelitian tidak mendukung Thoyibatun (2009), yang menyatakan kesesuaian sistem kompensasi berpengaruh negatif terhadap kecenderungan kecurangan akuntansi. Demikian juga dengan Aji (2013), yang menemukan bukti bahwa ada pengaruh yang negatif dan signifikan dalam penilaian penghasilan panitia pengadaan terhadap penyimpangan dalam pengadaan barang/jasa pemerintah.

Dari penelitian yang pernah dilakukan, faktor penghasilan merupakan salah satu faktor yang diduga berpengaruh terhadap terjadinya korupsi, termasuk didalamnya korupsi yang dilakukan melalui penyimpangan dalam kegiatan pengadaan barang/jasa pemerintah. Rijckeghem dan Weder (1997) dalam Lambsdorff (1999). Penghasilan aparatur pemerintah seharusnya dapat memenuhi kebutuhan hidup pegawai beserta keluarganya secara wajar. Ketidakseimbangan antara penghasilan yang diterima aparatur pemerintah dibandingkan dengan tingkat kebutuhan hidup pada tingkat yang wajar akan memaksa mereka untuk secara kreatif mencari tambahan penghasilan untuk memenuhi kebutuhan hidupnya.

Dalam penelitian ini, penghasilan panitia pengadaan dilihat dari beberapa dimensi yaitu keadilan internal, keadilan eksternal dan insentif yang memadai. Keadilan internal mensyaratkan bahwa tambahan honor yang diterima panitia pengadaan seimbang dengan beban kerja, tugas dan tanggung jawab sebagai panitia pengadaan. Keadilan eksternal mensyaratkan bahwa penghasilan yang diterima oleh panitia pengadaan setara dengan penghasilan yang diterima pada jabatan sejenis di sektor swasta / non pemerintah. Insenstif dikatakan memadai apabila penghasilan yang diterima oleh panitia pengadaan menciptakan kondisi yang tidak menyalahgunakan jabatan dan kewenangan yang dimiliki.

Hasil penelitian menunjukkan bahwa penghasilan panitia pengadaan tidak berpengaruh siginifikan terhadap terjadinya fraud pengadaan barang/jasa. Hal tersebut dapat terjadi disebabkan responden tidak seluruhnya meyakini bahwa penghasilan pantia pengadaan telah sesuai dengan beban kerjanya. Menteri Keuangan melalui Peraturan Menteri telah menetapkan standar biaya masukan untuk honor panitia pengadaan namun terkadang karena keterbatasan anggaran honor yang dibayarkan 
tidak sesuai dengan beban kerja masing-pasing panitia pengadaan. Penyebab selanjutnya adalah sebagian responden menyatakan bahwa penghasilan yang diterima oleh panitia pengadaan tidak setara dengan penghasilan yang diterima pada jabatan sejenis di sektor swasta / non pemerintah karena sebagian responden berpendapat bahwa di sektor swasta tidak ada tambahan honor kepada panitia pengadaan karena telah melekat pada tugas pokok bagian pengadaan. Kondisi lain yang menyebabkan adalah karena responden menyatakan bahwa penghasilan yang diterima oleh panitia pengadaan tidak diyakini menciptakan kondisi yang tidak menyalahgunakan jabatan dan kewenangan yang dimiliki. Hal tersebut sejalan dengan kondisi di Indonesia bahwa masih banyak dijumpai panitia yang menyalahgunakan wewenang meskipun telah diberikan tambahan honor panitia pengadaan.

\section{Pengaruh Sistem dan Prosedur Pengadaan Terhadap Fraud Pengadaan Barang/Jasa}

Hasil uji parsial (uji t) menunjukkan bahwa Sistem dan Prosedur Pengadaan mempunyai pengaruh yang signifikan terhadap fraud pengadaan barang/jasa $(\mathrm{Y})$. Terjadinya fraud pengadaan barang/jasa dapat di-kurangi dengan meningkatkan Sistem dan Prosedur Pengadaan. Hal ini sejalan dengan pendapat dari Sartono (2006), yang menunjukkan adanya pengaruh sistem dan prosedur pengadaan barang/jasa terhadap terjadinya fraud pengadaan barang/jasa dari sudut pandang eksternal instansi. Demikian juga dengan Jatiningtyas dan Kiswara (2011), hasil penelitian menunjukkan bahwa sistem dan prosedur pengadaan berpengaruh secara negatif dan signifikan terhadap terjadinya fraud pengadaan Hasil penelitian tidak mendukung pendapat Sartono (2006) dan Jatiningtyas dan Kiswara (2011), yang menunjukkan tidak ada pengaruh sistem dan prosedur pengadaan barang/jasa terhadap terjadinya fraud pengadaan barang/jasa dari sudut pandang internal instansi.

Aspek lain yang ikut menentukan jalannya sistem pengadaan barang/jasa adalah ketentuan dan prosedur pengadaan barang /jasa itu sendiri. Ketentuan dan prosedur pengadaan barang/jasa juga berpengaruh terhadap keberhasilan suatu sistem pengadaan barang/jasa pemerintah dalam mencapai tujuan yang telah ditetapkan (Thai, 2001).

Dalam penelitian ini sistem dan prosedur pengadaan diukur menggunakan empat instumen. Instrumen yang pertama yaitu ketentuan mengenai sistem dan prosedur pengadaan barang/jasa dapat dimengerti oleh pihak yang berkepentingan. (understandable). Sistem dan prosedur pengadaan yang mudah dimengerti baik oleh panitia dan penyedia barang diyakini dapat mengurangi resiko terjadinya fraud. Dengan sistem dan prosedur yang baik dan mudah dimengerti akan menjaga proses pelaksanaan pengadaan tetap berjalan sesuai dengan ketentuan. Pemerintah selalu berusaha memperbaiki sistem dan prosedur pengadaan, misalnya dengan menggunakan sistem baru yaitu Sistem Pengadaan Secara Elektronik (SPSE) meskipun langkah tersebut belum mampu menghilangkan fraud secara keseluruhan namun setidaknya langkah ini diyakini membatasi gerak para pelaku kecurangan.

Insrumen kedua adalah ketentuan mengenai sistem dan prosedur pengadaan barang/jasa dapat diterapkan (applicable) dalam kondisi yang sebenarnya. Sistem dan prosedur barang/jasa yang dapat diterapkan dalam kondisi sebenarnya diyakini mampu mengurangi terjadinya fraud. Kasus yang sering terjadi prosedur belum dapat diterapkan sehingga menyulitkan panitia pengadaan dalam melakukan pengadaan barang, akibatnya terdapat keterlambatan barang.

Instrumen ketiga adalah ketentuan mengenai sistem dan prosedur pengadaan barang/jasa mendorong terciptanya kompetisi secara fair diantara calon rekanan.Ketentuan mengenai sistem dan prosedur pengadaan barang/jasa yang mendorong terciptanya kompetisi secara fair diyakini mampu mengurangi terjadinya fraud. Dengan adanya kompetisi yang fair semua calon 
rekanan memiliki kesempatan yang sama dalam proses pengadaan, sehingga meminimalisir terjadinya KKN.

Instrumen keempat adalah ketentuan mengenai sistem dan prosedur pengadaan barang/jasa memberikan kesempatan yang cukup kepada calon rekanan yang merasa dirugikan untuk mengajukan complaint sebelum penandatangan kontrak. Sistem complaint yang baik diyakini mampu mengurangi terjadinya fraud. Dengan memberikan kesempatan kepada calon rekanan maka akan terwujud proses pengadaaan yang lebih adil dan apabila ditemukan permasalahan akan segera dicari solusi mengatasi masalah tersebut.

\section{Pengaruh Etika Pengadaan terhadap Fraud Pengadaan Barang/Jasa}

Hasil uji parsial (uji t) menunjukkan bahwa Etika Pengadaan mempunyai pengaruh yang signifikan terhadap fraud pengadaan barang/ jasa (Y). Terjadinya fraud pengadaan barang/ jasa dapat dikurangi apabila seluruh pihak yang terkait menggunakan etika pengadaan di setiap tahapan proses pengadaan.

Hasil penelitian sejalan dengan Sartono (2006), yang menunjukkan bahwa etika pengadaan berpengaruh secara negatif dan signifikan terhadap terjadinya fraud pengadaan. Sementara Jatiningtyas dan Kiswara (2011), menunjukkan bahwa etika pengadaan berpengaruh secara negatif dan signifikan terhadap fraud pengadaan. Hasil tersebut sependapat dengan Aji (2013), yang menemukan bukti bahwa ada pengaruh yang negatif dan signifikan dalam etika pengadaan terhadap penyimpangan dalam pengadaan barang/jasa pemerintah. Hasil penelitian tidak mendukung pendapat Sartono (2006) dan Jatiningtyas dan Kiswara (2011), yang menunjukkan tidak ada pengaruh etika pengadaan terhadap terjadinya fraud pengadaan barang/jasa dari sudut pandang internal instansi

Etika pengadaan berkaitan dengan kelaziman dalam praktek dunia usaha yang dianggap akan menciptakan sistem persaingan usaha yang adil. Etika dalam pengadaan barang/ jasa akan mencegah penyalahgunaan wewenang atau kolusi untuk keuntungan pribadi atau golongan yang secara langsung atau tidak dapat merugikan negara.

Dalam penelitian ini etika pengadaan diukur menggunakan tiga instrumen berikut yaitu tidak ada calon rekanan yang menjanjikan, menawarkan atau memberikan suatu imbalan/ hadiah kepada Panitia Pengadaan atau Pejabat pada intansi yang mengadakan tender. Tidak ada peserta tender yang hanya bertindak sebagai calo di dalam pengadaan barang/jasa dan discount/ potongan harga yang diberikan oleh rekanan (jika ada) selalu dicantumkan dalam faktur/ dokumen penagihan kepada pemberi kerja.

Praktek-praktek diatas merupakan etika pengadaan yang harus dijunjung tinggi oleh seluruh pihak yang terlibat dalam proses pengadaan barang/jasa. Apabila ada salah satu pihak yang melanggar etika maka fraud tidak akan mungkin dapat dihindari. Adanya calon rekanan yang menjanjikan atau menawarkan hadiah biasanya membuat panitia pengadaan yang mempunyai integritas rendah menjadi berubah haluan ke perilaku yang melanggar ketentuan. Karena berdasarkan teori, fraud dapat terjadi karena adanya kesempatan.

Adanya calo juga memperburuk pelaksaaan pengadaan barang/jasa. Karena penyedia bisa saja tidak kompeten sehingga barang yang diperjanjikan tidak sesuai dengan kebutuhan. Adanya calo juga membuat harga barang/jasa yang diadakan menjadi lebih mahal, karena mata rantai menjadi lebih panjang, dan masingmasing pihak ingin memperoleh keuntungan, akibatnya barang/jasa yang dibeli adalah barang yang mempunya kualitas kurang baik karena harga yang murah.

Pemberian potongan harga dari rekanan adalah hak negara, sehingga pada saat proses pengadaan ketika ada potongan harga wajib dicantumkan dalam faktur. Praktek yang tidak sehat yang membiasakan tidak mencantumkan 
potongan harga bisa menimbulkan budaya korupsi. Hal ini terjadi apabila budaya tersebut menjadi kebiasaan dengan meminta potongan harga kepada rekanan, tetapi faktur yang ditagihkan ke negara menggunakan harga yang sesungguhnya.

\section{Pengaruh Sistem Pengendalian Internal terhadap Fraud Pengadaan Barang/Jasa}

Hasil uji parsial (uji t) menunjukkan bahwa Sistem Pengendalian Internal mempunyai pengaruh yang signifikan terhadap fraud pengadaan barang/jasa (Y). Terjadinya fraud pengadaan barang/jasa dapat dikurangi apabila Sistem Pengendalian Internal telah berjalan dengan baik.

Hasil penelitian sejalan dengan Sartono (2006), yang menunjukkan bahwa sistem pengendalian internal berpengaruh secara negatif dan signifikan terhadap terjadinya fraud pengadaan. Sementara Thoyibatun (2009), dalam hasil penelitian-nya menyatakan kesesuaian sistem pengendalian internal berpengaruh negatif terhadap kecenderungan akuntansi. Demikian juga dengan Jatiningtyas dan Kiswara (2011), menemukan hasil bahwa pengendalian internal berpengaruh secara negatif dan signifikan terhadap terjadinya fraud pengadaan. Arifianti, dkk (2015), membuktikan bahwa sistem pengendalian internal yang baik berimplikasi positif untuk menekan terjadinya fraud. Hasil penelitian tidak mendukung pendapat Sartono (2006) dan Jatiningtyas dan Kiswara (2011), yang menunjukkan tidak ada pengaruh sistem pengendalian internal terhadap terjadinya fraud pengadaan barang/jasa dari sudut pandang internal instansi.

Dalam penelitian ini instrumen yang digunakan dalam mengukur sistem pengendalian internal adalah menggunakan 5 unsur yang ada di dalam pengendalian internal. Unsur yang pertama adalah lingkungan pengendalian. Lingkungan pengendalian yang baik dalam proses pengadaan, akan menurunkan potensi terjadinya fraud. Lingkungan pengendalian pada proses pengadaan diwujudkan dalam pembuatan pakta integritas oleh panitia pengadaan, adanya sikap yang independen dari panitia pengadaan, adanya struktur organisasi yang baik dan memadai yang mendukung panitia pengadaan untuk bekerja secara obyektif. Apabila lingkungan pengendalian baik maka akan membatasi ruang gerak pelaku yang mencoba berbuat kecurangan. Para pelaku tidak mungkin bekerja sendiri, sehingga apabila lingkungannya sudah baik maka kemungkinan terjadinya fraud menjadi kecil.

Unsur kedua adalah penilaian resiko. Proses penilaian resiko dalam proses pengadaan antara lain adalah melakukan identifikasi kerugian negara atau identifikasi adanya ketidak efisien dan efektif dalam proses pengadaan. Apabila hal ini telah dilakukan maka fraud akan dapat dihindari. Karena sebelum proses pengadaan dilaksanakan panita telah mampu melakukan penilaian resiko sehingga dapat memutuskan tindakan apa yang harus dilakukan dalam rangka menghadapi resiko yang mungkin timbul yang dapat mengganggu pencapaian tujuan dari pengadaan.

Unsur ketiga adalah kegiatan pengendalian. Dalam proses pengadaan, kegiatan pengendalian adalah kegiatan yang dilaksanakan dalam rangka pencapaian tujuan pengadaan itu sendiri. Kegiatan tersebut antara lain terdapat pemisahan fungsi, yang dalam praktek pengadaan diwujudkan dalam pemisahan antara panitia pengadaan dan panitia penerima barnag/ jasa. Kegiatan pengendalian yang lain adalah adanya otorisasi pada setiap transaksi, yang dalam praktek diwujudkan dengan ketentuan dan wewenang pejabat yang menandatangani kontrak, pejabat yang melakukan pembayaran. Apabila kegiatan pengendalian dilakukan maka fraud bisa dikurangi.

Unsur keempat adalah informasi dan komunikasi. Dalam proses pengadaan, informasi komunikasi diwujudkan dalam sistem dan informasi yang mampu memberikan informasi yang relevan. Dalam praktek pengadaan yaitu 
bagaimana informasi yang diberikan bisa relevan terkait dengan pengadaan, sehingga tidak ada pihak yang dirugikan dan semua informasi handal sehingga proses pengadaan berjalan lancar. Informasi dan komunikasi yang kurang baik bisa menghambat pelaksanaan proses pengadaan, sebagai contoh kurangnya informasi terkait spesifikasi teknis barang akan berakibat pada pengadaan barang yang tidak sesuai dengan spesifikasi.

Unsur keempat adalah pemantauan. Dalam proses pengadaan, pemantauan barang/ jasa diwujudkan dalam pemantauan tahapan prosedur pengadaan dan adanya supervisi atas pengadaan barang/jasa yang memadai. Adanya pemantauan yang baik maka akan menurunkan potensi terjadinya fraud. Apabila setiap tahapan dilaporkan maka akan memperkecil kemungkinan timbulnya permasalahan dalam proses pengadaan. Misalnya pengadaan berupa konstruksi gedung, jika setiap tahapan pekerjaan dilaporkan maka kemungkinan kegagalan atau keterlambatan proses pembangunan bisa diketahui dari awal. Begitu juga dengan supervisi yang memadai, adanya pengawasan yang baik akan mengurangi terjadinya fraud.

\section{Simpulan, Keterbatasan, dan Implikasi Hasil Penelitian}

Penelitian ini bertujuan untuk memberikan bukti empiris dan menganalisis pengaruh kualitas panitia pengadaan, penghasilan panitia pengadaan, sistem dan prosedur pengadaan, etika pengadaan dan sistem pengendalian internal terhadap terjadinya fraud pengadaan barang/jasa. Berdasarkan hasil penelitian dapat disimpulkan bahwa kualitas panitia pengadaan, sistem dan prosedur pengadaan, etika pengadaan dan sistem pengendalian internal berpengaruh signifikan terhadap terjadinya fraud pengadaan barang/jasa. Sementara variabel penghasilan panitia pengadaan tidak berpengaruh signifikan terhadap terjadinya fraud pengadaan barang/ jasa.
Beberapa keterbatasan yang kemungkinan dapat berpengaruh dalam penelitian ini adalah responden yang digunakan dalam penelitian ini hanya responden yang merupakan auditor internal di Inspektorat Jenderal Kementrian Kesehatan. Besar kemungkinan bila responden diambil dari pihak-pihak yang terkait langsung dengan pengadaan barang/jasa berbasis elektronik akan memberikan hasil yang berbeda. Keterbatasan lainnya adalah penelitian ini kurang dapat menjelaskan faktor-faktor yang mempengaruhi fraud pengadaan barang/jasa karena data yang digunakan adalah data primer yang berasal dari kuesioner. Seperti yang telah diketahui sebelumnya bahwa, data yang didapatkan dari kuesioner biasanya bersifat subyektif (berdasarkan opini masing-masing responden) sehingga keobyektifitasannya sering diragukan.

Dari hasil penelitian yang telah dilakukan, ada beberapa saran yang dapat disampaikan bahwa secara parsial terdapat pengaruh yang signifikan antara Kualitas Panitia Pengadaan, Sistem dan Prosedur Pengadaan, Etika Pengadaan dan Sistem Pengendalian Internal terhadap terjadinya fraud pengadaan barang/ jasa, sehingga pembuat kebijakan dan auditor perlu mengetahui faktor-faktor yang dapat menaikkan dan menurunkan potensi terjadinya fraud pengadaan barang/jasa.

Lebih jauh peneliti menyarankan agar pembuat kebijakan perlu terus menjaga dan memantau kualitas panitia pengadaan, sistem dan prosedur pengadaan, penerapan etika pengadaan dan sistem pengendalian internal agar dapat mengurangi potensi terjadinya fraud.

Sebagaimana dijelaskan sebelumnya, hasil penelitian menunjukkan pengaruh yang signifikan antara kualitas panitia pengadaan, sistem dan prosedur pengadaan, etika pengadaan dan sistem pengendalian internal terhadap terjadinya fraud pengadaan barang/jasa. Secara teoritis, hal ini dapat mendorong arah riset selanjutnya untuk lebih spesifik meneliti faktorfaktor yang mempengaruhi fraud pengadaan 
barang/jasa sehingga dapat menghasilkan teori baru khususnya dalam rangka pencegahan dan pendeteksian fraud. Untuk penelitian selanjutnya agar hasil penelitian lebih obyektif perlu dikaji penggunaan instrumen yang dapat diukur secara kuantitatif.

\section{Daftar Referensi}

Aji. T. W. (2013). Analisis Faktor-Faktor Yang Mempengaruhi Penyimpangan Dalam Pengadaan Barang dan Jasa Pemerintah (Kajian Empiris di Provinsi Jawa Tengah. Tesis Tidak Dipublikasikan. Universitas Diponegoro.

Committee of Sponsoring Organizations of Teadway Commision (COSO), Internal Control Integrated Framework, Adendum (1994), AICPA Publication, New York, 1992.

Detik.com, 27 April 2017.

Gelderman, C.J., Ghijsen,P.W, Th., Brugman, M.J., (2006), Public Procurement and EU Tenderring directives - explaining non compliance, Faculty of Management Sciences, Open University of Netherlands, Heerlen, The Netherland.

Ghozali, (2013), Imam, Aplikasi Analisis Multivariate dengan Program IBM SPSS 21 Update PLSRegresi, Edisi 7, Badan Penerbit Universitas Diponegoro, Semarang.

Jatiningtyas, Nurani, (2011), Analisis FaktorFaktor yang Mempengaruhi Fraud Pengadaan Barang/Jasa pada Lingkungan Instansi Pemerintah di Wilayah Semarang, Skripsi Universitas Diponegoro.

Suharti, dkk, (2015), Jurnal Pengadaan, Volume 3, Nomor 3, November.

KPK, Direktorat Penelitian dan Pengembangan, Integritas Sektor Publik Indonesia Tahun 2011, 2012 dan 2013, Jakarta.

Mulyadi. (2002), Auditing. Edisi ke enam, Salemba Empat, Jakarta.

Mulyanto, H., Wulandari, A, (2010), Penelitian; Metode dan Analisis, CV Agung, Semarang.
Peraturan Pemerintah Republik Indonesia Nomor 60 Tahun 2008 Tentang Sistem Pengendalian Intern Pemerintah.

Organization of Economic Country Development, (2002), Government Capacity to Assure High Quality Regulation, www.adb. org 9 September 2005.

Priantara, D, (2013), Fraud Auditing and Investigation, Penerbit Mitra Wacana Media, Jakarta.

Rijckeghem, C.V., Weder, B. (1997). Corruption and The Rate of Temptation: do Low Wages in the Civil Services Cause Corruption? IMF Working Paper.

Rini Arifianti, dkk, (2015), Perspektif Triangle Fraud Theory Dalam Pengadaan Barang/ Jasa di Pemerintah Provinsi NTB, Jurnal Infestasi, Vol 11 No 2 Desember Hal 195213.

Sartono, (2006), Analisis Faktor-Faktor yang Mempengaruhi Terjadinya Penyimpangan Pengadaan Barang/Jasa, Tesis Tidak Dipublikasikan, Universitas Indonesia.

Sawyer B. Lawrence, A. Ditternhofer, Mortiner., Scheiner J, Sawyer's Internal Auditing; The Practice of Modern Internal Auditing, Fifth Edition, The Institute of Internal Auditors, Florida, (2003).

Sulistiyowati, T. (2007). Pengaruh Kepuasan Gaji Dan Kultur Organisasi Terhadap Persepsi Aparatur Pemerintah Daerah Tentang Tindak Korupsi. JAAI Vol. 11 No.1, Juni 2007:47-66.

Sindonews.com tanggal 26 Januari 2015.

Thai, K.V. (2001). Public Procurement Reexamined. Journal Of Public Procurement, Volume 1, Issue 1, 9-50.

Tuanakotta, T. M. (2007). Akuntansi Forensik dan Audit Investigasi. Lembaga Penerbit Fakultas Ekonomi Universitas Indonesia, Jakarta.

Thoyibatun, (2009), Analysing The Influence of Internal Control Compliance And Compensation Sustem Against Unethical Behavior And Accounting Fraud Tendency 
(Studies at State University in East Java, Simposium Nasional Akuntansi XII, Palembang.

Wilopo, R, (2006), Pengaruh Pengendalian Internal Birokrasi Pemerintah dan Prilaku Tidak Etis Birokrasi Terhadap Kecurangan Akuntansi di Pemerintahan: Persepsi Auditor Badan Pemeriksa Keuangan, Jurnal Ventura, Volume 11, Nomor 1, April 2008.

Wilopo. (2006). Analisis Faktor-Faktor Yang Berpengaruh Terhadap Kecenderungan Kecurangan AKuntansi Studi Pada Perusahaan Pubolik dan Perusahaan Badan Usaha Milik Negara. Simposium Nasional Akuntansi IX, Padang.

World Bank. (2001). Indonesia Country Procurement Assessment Report : Reforming the Public Procurement System. www.worldbank.org, 12 September 2005. 